\title{
Ethiopian Urban Land Lease Policy Analysis Implementation: Case Study on A.A. City Administration
}

\author{
Asfaw Takele ${ }^{1}$
}

\section{'Ethiopian Human Rights Commission; Josef Tito Street; Guinea Conakry Street; Africa 'Godana' Street; Addis Ababa, Ethiopia \\ Email:Takeleasfaw279@gmail.com}

Licensed:

This work is licensed under a Creative Commons Attribution 4.o License.

Keywords:

Policy

Land

Urban

Price Setting

Proclamation.

\begin{abstract}
The term land has a very complex concept. It is this reason that some people called it as a double Dutch language. The demand for land stock derives first from the need for agricultural goods and housing, which is essentially a demand for land services. Many well known writers who were live at different times and place had described the importance of land very well. This is why, many countries and governments decide as the land to be as government property. It is this true that the government of Ethiopia publicized the urban land is the state property by declaring through the proclamation of 721/2011 Urban land policy. When we came to its implementation, however, may not as good as it was expected. Such as: setting price, affordability systems, monitoring and controlling mechanisms, etc. So, as a researcher, I want to deal with this situation by comparing the implementation practice and the policy sayings. This study had employed qualitative research design; internet based data collection mechanism; qualitative or word mouth method of analysis. I finally, by this study after all got results like: there are different experiences which are practiced by different countries; there are differences in designing, tenure admitting and holding system, price specification and land and property, market system, as well as implementations of urban land lease policy among countries; though, there is no one consensus on the government or state ownership on urban land tenure type in the Ethiopian context, perhaps especially in the Addis Ababa Context; it is based on different and very crucial assumptions which have legal, social, and economic rationales in adopting the current Ethiopian Urban land lease policy; etc. standing from these findings, I recommends that: I can say or recommend that the urban land lease policy is the best and likely be pretty policy choices of cities like it what happen to the current situation in Addis Ababa, Ethiopia. In addition to that, I would likely recommend as it is better or pretty good for governments or for countries themselves if and only if they can follow or adopted the land lease policy tenure system than other tenure types, perhaps especially from the private tenure land policy type.
\end{abstract}

\section{Introduction}

The term land has a very complex concept. It is this reason that some people called it as a double Dutch language. The demand for land stock derives first from the need for agricultural goods and housing, which is essentially a demand for land services. Secondly, it arises from the desire for infrastructure and environment-related projects, a demand oft en independent of land prices as it is determined by government objectives and other concerns. Thirdly, it takes the form of an asset demand in view of the financial asset characteristics of the land stock.

Bacry, Sileshi, and Admit (2009) also addressed that the role [of land is, therefore, very vast which is] as a hedge against inflation, as collateral for credit operations, and as a component of the diversification strategies of economic agent is subsumed in this third type of demand. The supply of land for the rural and urban sectors is determined by nature - availability, topography, soil fertility - and by the volume and quality of prior investments, including structures. Regulatory constraints affect both the demand and supply of land (Bacry et al., 2009).

According to this study, different studies suggest that "land and real estate assets account for 45 to 75 percent of wealth in developing countries, thus playing a unique dual role of serving as inputs into production activities in agriculture, industry, and services as well as consumption by households and commercial entities of residential and commercial real estate and infrastructural services" 
This is why the reason that the government of Ethiopia publicized the land is the state property by setting a proclamation of 721/2011. However, there are different contrary views such as blames and/ or appreciations regarding to this policy issue and on the proclamation of 2011 . It is the same true to the case of urban land administration of Addis Ababa city Administration. This is why the reason I am initiated to compose an analysis on this issues.

This is made especially by standing from the situation what by today happen in Addis Ababa regarding land and land market as well as by assessing the response of stakeholders (people or residence of the city) from interview approach in the following points (Ian, 2000 Cited on Bacry et al. (2009)). These are:

- The link between land policy and development;

- The experiences of other countries and cities to see if Ethiopia's experience is consistent with conditions in developing and developed countries;

- Policy statements and major development programs of the government on land related matters with a view to analyzing and understanding their implications on land administration systems; and

- Price setting mechanism to see whether it matches with theoretical framework and country objectives.

So, standing from the above issues about land I am very initiated to start or scheduled study on what looks like the land policy of Addis Ababa? What accurate changes can bring to solve the problem of stake holders? What others say? What gaps did it have? What would be best for the city administration do if there are any gaps observed there?

My study as it analysis on the current Ethiopian perhaps, especially Addis Ababa, land policy and it's the implementation; I will use an assessment method of study. My term paper study is mainly a qualitative research type; has cross-sectional time frame; will use secondary data and use checklists to co collect data from secondary sources; and finally use qualitative or word mouth types of presenting, analyzing, interpreting the collected data.

\section{Literature Review}

This section mainly deals about the concepts on land lease policy; experiences of developing and developing countries in land lease policy; and current situations about land lease policy and its implementations in Ethiopia.

\subsection{Concepts about Lund Lease Policy}

The definition of land used to be: "a physical entity in terms of its topography and spatial nature"; this is often associated with an economic value, expressed in price per hectare at ownership transfer. The broader, integrative or holistic view takes into account the physio-biotic and socio-economic resources of the physical entity. Because of this, there is no one and single definition on the term land. However, the mostly popularized and very brief description given to this which is a complete definition may therefore be the following one (already used in the documentation for the Convention to Combat Desertification) (United Nations General Assembly Report, 1994):

"Land is a delineable area of the earth's terrestrial surface, encompassing all attributes of the biosphere immediately above or below this surface including those of the near-surface climate the soil and terrain forms, the surface hydrology (including shallow lakes, rivers, marshes, and swamps), the near-surface sedimentary layers and associated groundwater reserve, the plant and animal populations, the human settlement pattern and physical results of past and present human activity (terracing, water storage or drainage structures, roads, buildings, etc.)."

This definition conforms to:

1. Land system units. Landscape-ecological units or unites exterior, as building blocks of a watershed (catchment area) or a python-geographic unit (biome).

2. The definition of a natural land unit as defined above is distinctive from an administrative unit of land (territories) which can be of any size (individual holding, municipality, province, state, etc.) and which normally encompasses a number of natural units or parts of them.

3. The components of the natural land unit can be termed land resources, including physical, bionic, environmental, infrastructural, social and economic components, inasmuch as they are fixed to the land unit.

4. Included in the land resources are surface and near-surface freshwater resources. Part of this move through successive land units, but then the local flow characteristics can be considered as part of the land unit. The linkages between water and land are so intimate at the management level that the water element cannot be excluded (land as a unit intermixed with water, with its land use in part depending on access to that water, and the unit at the same time affecting the quality and quantity of the passing water

5. Underground geological resources (oil, gas, ores, precious metals), and deeper geo-hydrological resources that normally bear no relation to the surface topography such as confined aquifers, are excluded from the group of components of the natural land unit, although it is recognized that some countries consider them as part of individual land ownership (and hence with rights to exploit or sell them). 
In this holistic approach, a natural unit of land has both a vertical aspect - from atmospheric climate down to ground water resources, and a horizontal aspect - an identifiable repetitive sequence of soil, terrain, hydrological, and vegetative or land use elements." So, to govern this is needs a policy guide and direction which is called land Policy.

Urban Land policy is a kind of policy as well as part of the national policy of countries. Such policies generally relate to economic development, social justice and equity, and political stability.

The land policy a policy which include or promote the provision of security of tenure, improve access to credit, land reform, land titling and the resolution of issues relating to traditional or customary tenures, facilitate special attention to provision of land for the poor, ethnic minorities and women, facilitate land use and physical planning, real property taxation, measures to prevent land speculation and land disputes.

Insofar as land is a factor of production and a store of wealth, it is also a source of political power, especially in societies where access to other assets is limited. The evolution of property rights shows that landowners have had upper hand in shaping policies that favour their interests, a situation that is still prevalent in some industrial and many developing countries.

\subsection{Experiences of Developed Countries Regarding to Land Lease Policy:}

Regarding to governing, or administering land countries (either developed or developing) had have different experiences. This means countries are differ in ways of land permit system, in way of land acquisition system, tenure type, price specification on land and property market governing system, or extra.

\subsection{Current situations about the Land Lease Policy and its practices or implementation:}

The Ethiopian Land Policy is ratified and come in to being because of different reasons. On one hand:

- it is provided by Article 40 of the Constitution of the Federal Democratic Republic of Ethiopia that land is the property of the State and the people of Ethiopia and that its use shall be subject to specific regulation by law;

- the sustained rapid economic growth registered across sectors and regions in the country has steadily and exponentially increased the demand for urban land, and such development requires prudent and responsive land resources management;

- the assumptions on the prevalence of good governance is a foundational institutional requisite for the development of an efficient, effective, equitable and well functioning land and landed property market, the sustenance of a robust free market economy and for building transparent and accountable land administration system that ensures the rights and obligations of the lessor and the lessee

\subsection{On the other Hand}

Land as it is described in the introduction part of this paper, is sources of all things (such as: source of income, source wealth, the area of which economic activities run on it like livestock's, it is a place where a house or shelter is built, etc things). Because of these things it is unquestionable that land should be a state owned property. The report made by Addis Ababa Chamber of Commerce Research Team (Mathewos, Abebe, छ Solomon, 2011) indicates the same to this idea that "almost all individuals that run activities have applied to acquire land whether they are from the micro-small scale activities or big real estate developers or the one who needs to establish a small shop, etc. The actual fact is that all activities need a place i.e. land, which is a scarce resource".

Of course, there are different arguments on its ownership type (either could be a government or private).

If one were to characterize the issues surrounding the debate with regard to land policy in Ethiopia in few words, one would perhaps aptly say that it is basically a polarized debate between 'the equity versus tenure security cum efficiency' paradigms with some groups of course preferring to go for the best of both worlds or refusing to subscribe to any 'either or' constructs of this type.

While advocates of public ownership envisage to forestall excessive landlessness (including ensuring rights over the so-called ancestral land) and thereby trying to provide a kind of 'universal' access to land, the opponents are anxious to tackle the abysmal declines in agricultural productivity and land quality, which they think are the outcomes of the flawed tenure regime that has manifested itself in the form of tenure insecurity, land degradation, land scarcity, land fragmentation, etc.

In the past three decades, the supply of land and housing construction did not correspond to the housing needs. Therefore, there is a mismatch between housing supply and housing need by the alarming growing population, $5.5 \%$ per annum in the city.

This has brought squatting to the inner city and informal parcellation of plots. Land for dwelling house construction has often been allocated far away (approximately $10 \mathrm{~km}$ ) from the nearest service where basic infrastructure is difficult to find. Therefore, either the dwellers prefer to go to the informal land provider close to the developed area or they leave the land idle for waiting while waiting for infrastructure.

Because of these different reasons Government of Ethiopia makes Land under state ownership. This policy and its attendant /LA/ practices have perpetuated a long running debate that started in the 1960s. The debate is so impassioned that it at times becomes rabid and holds the policy responsible for everything that goes wrong in the country. 
There are a lot of practices in designing and implementing Land Policy in countries as the way it possible suits to the administrative issues of the countries. Under conditions of rapid urbanization, competition for secure and serviced land increases.

As the Addis Ababa University Research Team (Bacry et al., 2009) addressed that this places [land] pressure on existing tenure systems and requires governments to formulate policies, which encourage efficient land use and improve accessibility to land, without sidelining the urban poor. The central policy issue, hence, becomes what forms of land tenure best achieve these objectives of efficiency and equity.

In designing a strategy it is important to recognize that almost every country will require a range of different strategies depending on the relationship of humankind to land in each specific region in the specific country. In simple terms these arrangements include:

- Cities and urban areas, where active land markets operate on titled land;

- Cities and urban areas, occupied by informal settlements (squatter, illegal or low cost systems outside the formal or regulatory structures);

- High value agricultural lands which are titled and are part of the formal land market;

- Private untitled lands in rural areas and villages;

- Informal or illegal settlements in rural areas, especially in government forests;

- Lands which are subject to indigenous rights, such as Adat lands in Indonesia;

- Lands in all categories which are the subject of claims from previously dispossessed persons; and

- Government or state lands, reserves and forests;

To some degree these categories are common to all developing (and many developed) countries. The Land Administration Authority of Addis Ababa has assessed the last 8 years (from 1994 to 2002) incident to indicate the way how land lease came into effect and the situation of land market in the city. They have reached to the conclusion that the policy could not meet the objective with respect to renewal of the core area, efficient use of land and attract in investment (Nega, 2005).

\section{Research Methodology}

This paper tried to analyze and evaluate the Ethiopian land Policy issue of Ethiopia by taking the Addis Ababa case. This research, therefore, uses it different research approach, object selecting method and at last suitable data collecting mechanisms. These are:

- As far as the study the Land Policy issue of Ethiopia in refereeing with the Addis Ababa case. This research, therefore, is a case study research;

- In fact it describes about the current issue of Addis Ababa land policy, the papers research approach or design is explanatory approach.

- Mainly Qualitative data types will employee to describe the paper well.

- Lastly this paper use qualitative description, analysis, and interpretation of data. But if Necessary, uses tables, graphs, and charts to present, analyze and the collected, analyzed and interpreted data of the paper findings respectively.

\section{Results}

As it is discussed continuously starting from introduction part of this paper, this study finally come up with different results on the general analysis of the Ethiopian Urban Land lease Policy bay taking as a case study of the Addis Ababa city administration situations on it. This means the results of the study analysis or this paper are:

- First of all there is no one single definition on the term land or either urban land. However, the most familiar and brief definition of land as it is discussed on [] is "a natural unit of land has both a vertical aspect - from atmospheric climate down to ground water resources, and a horizontal aspect - an identifiable repetitive sequence of soil, terrain, hydrological, and vegetative or land use elements." So, to govern this is needs a policy guide and direction which is called land Policy";

- To govern and/ or administer this big deal of a country needs a policy direction or land policy. This land policy is therefore defined as policy a policy which include or promote the provision of security of tenure, improve access to credit, land reform, land titling and the resolution of issues relating to traditional or customary tenures, facilitate special attention to provision of land for the poor, ethnic minorities and women, facilitate land use and physical planning, real property taxation, measures to prevent land speculation and land disputes;

- There are different experiences which are practiced by different countries;

- There are differences in designing, tenure admitting and holding system, price specification and land and property ,market system, as well as implementations of urban land lease policy among countries;

- Though, there is no one consensus on the government or state ownership on urban land tenure type in the Ethiopian context, perhaps especially in the Addis Ababa Context; it is based on different and very crucial assumptions which have legal, social, and economic rationales in adopting the current 
Ethiopian Urban land lease policy;

- Though, there are different gaps in the implementation and practices; unlike to land policy of proclamation number 174/1974 the current Urban Land lease policy (721/2012) of Ethiopia had been brings changes on the different features of towns and cities perhaps especially the case study city Addis Ababa.

\section{Discussion}

From the above parts of this paper one can, of course, understand that there are different types of land policy as far as there are different tenure hold systems; there are no one single agreements or consensuses among countries on definition of the term land; there are different land administration types; differences in designs and cause or reasons in design and implementations of land policy; etc.

However, standing from the review literatures and result parts of this paper as well as from my experiences in policy making I can say or recommend that the urban land lease policy is the best and likely be pretty policy choices of cities like it what happen to the current situation in Addis Ababa, Ethiopia.

In addition to that, I would likely recommend as it is better or pretty good for governments or for countries themselves if and only if they can follow or adopted the land lease policy tenure system than other tenure types, perhaps especially from the private tenure land policy type.

\section{Conclusion}

This time it is observed that countries follow or adopted different policies in administering their scare resources which is land. Unlikely to all in some circumstances it is observed on some countries on which the policy they adopt in administering land as it cause them to conflict, inequality, economic depressions and in justice, luck of good governance in among its citizens. Because of this reason that I am initiated on studying and analyzing on what looks like and what it is be on the urban land policy of Ethiopia, perhaps especially the case of Addis Ababa.

I had used different study methodologies, reviewing different literatures try to assess on what is exactly in the ground in Ethiopia in the current situations of its urban land policy.

I am, finally, come up with the different results and based on the results I recommend that the Ethiopian Urban Land lease policy of this time bears different benefits and changes to the city structure of Addis Ababa as well as bearing different importance to the country's economic, social, political and legal benefits.

\section{References}

Bacry, Y., Sileshi, T., \& Admit, Z. (2009). Private sector development Hub/Addis Ababa chamber of commerce and sectoral associations: Land lease policy in Addis Ababa. Research Team; Produced and Distributed by the Addis Ababa Chamber of Commerce and Sectoral Associations with financial support from the Swedish Agency for International Development Cooperation, Sida. Retrieved from http://www.ethiopianchamber.com/Data/Sites/1/psd-hub-publications/land-lease-policy-in-addis-ababa.pdf. [Accessed July 21, 2016].

Mathewos, A., Abebe, Z., \& Solomon, B. (2011). Assessment of urban development practices on business expansion in Ethiopia. Produced and Distributed by the Addis Ababa Chamber of Commerce and Sectoral Associations with financial support from the Swedish Agency for International Development Cooperation, Sida.Retrieved from http://ethiopianchamber.com/Data/Sites/1/psd-hub-publications/assessment-of-urban-development-practiceson-business-expansion-in-ethiopia.pdf [Accessed July 17, 2016].

Nega, W. (2005). Master's program in urban management and development: Who are benefiting? The urban land lease $\begin{array}{lllll}\text { policy } & \text { (case } & \text { Addis } & \text { Ababa). }\end{array}$ http://www.lth.se/fileadmin/hdm/alumni/papers/umd2005/umd2005-04. [Accessed July 16, 2016].

United Nations General Assembly Report. (1994). United Nations convention to combat desertification: Elaboration of an international convention to combat desertification in countries experiencing serious drought and/or desertification, particularly in Africa. Retrieved from http://www.unccd.int/Lists/SiteDocumentLibrary/conventionText/conv-eng.pdf. [Accessed August 13, 2016]. 